\title{
EDUCATION IN PENITENTIARIES AND REMAND CENTRES AS A FORM OF IMPACT INSTRUMENTS
}

\section{Introduction}

The need to understand the concept of teaching under conditions of penitentiary isolation in prisons and remand centers, which fall within the jurisdiction of the Justice Minister of the Republic of Poland, requires multi-layer and interdisciplinary analysis. In the publication herein, one will therefore encounter references to theoretical knowledge in the field of law, psychology and pedagogy as well as information from practitioners, namely pedagogues and psychologists serving in penitentiary units and teachers working in prison-affiliated educational establishments but also lecturers running their own courses.

\section{Legal Background}

Teaching, along with work, cultural and educational activities, leisure and sports is the major method of penitentiary resettlement (Machel, 2003). The paramount legal act which permits the incarcerated to educate while serving their sentence is the act from the $6^{\text {th }}$ of June 1997 - The Executive Penal Code. Article 67 of PEC states that "execution of prison sentence shall activate in the sentenced person the willingness to cooperate in the process of shaping socially desirable attitudes, especially the sense of responsibility and the need for compliance with law in order to forbear from resorting to crime." (Act from 6 June 1997, article 67, Lelental, 2010, p.316). $\$ 3$ of the article specifies the instruments of influence on the convicts:

"The influence on convicts, while respecting their rights but requiring to fulfill obligations, should consider ... education ... in the first place." (therein, p.316). Additionally, article 102 in section 5 talks about the right of the sentenced to education and self-education. Within the "Penal Executory Code" there are further details regulating convicts education given in Chapter 6 "Tutelage". Articles 
from 130 to 134 cast more light on the frame principles of education in penitentiaries. (Lelental, 2010).

The guidelines on conducting educational activities within the premises of penitentiaries and remand centers are given in The Ordinance of The Ministry of Justice from the $13^{\text {th }}$ of February 2004 (Dz.U.04.37.337) concerning detailed principles and methodology of education in penitentiaries and The Instruction No. 1/2011 of The Director General of The Prison Service from the $13^{\text {th }}$ of July 2011 concerning detailed education methodology in schools and course training in penitentiaries and remand centers.

\section{Organization and Methods of Education}

The history of education as one of the methods of influence on prisoners dates back to the $16^{\text {th }}$ century, when in Brideville in England and Amsterdam in the Netherlands appeared the first houses of reformation and forced labour in which inmates were trained to work. Former prisons and the prison sentence execution were of transparent retaliatory nature. The actual transition of penitentiary thought took place no sooner than in the beginning of the $18^{\text {th }}$ century owing to the Pope Clement XI who contributed to the inception of San Michele resettlement asylum. Another milestone in the history of penitentiary systems, which came in the second half of the $18^{\text {th }}$ century, was the Vilain's creation of the Separate System which assumed certain extent of prisoners segregation to avoid reciprocal depravity and resettlement through work (Machel, 2003). The question of penitentiary education, and in effect progressive system, was introduced by a French penologist, whose counterparts on Polish territory were, inter alia, Mirosław Nakwaski and Fryderyk Skarbek. The Standard Minimum Rules for the Treatment of Prisoners created by the United Nations in 1955 were a consequence of penitentiary thought evolution (Machel, 2003). While discussing the topic of education organized by Polish prison service one should in the first place highlight the fact that schools affiliated with penitentiaries are institutions with distinct teaching personnel. The teachers employed therein are neither pedagogues nor psychologists of penitentiary departments. During their cooperation with a penitentiary they consider the specific character of teaching in isolation conditions and the necessity to secure order, discipline and safety (The Ordinance of The Ministry of Justice from the $13^{\text {th }}$ of February 2004, Dz.U.04.37.337). The director of the penitentiary is obliged to secure conditions and financial means vital for school operation. If an inmate was given a permission to begin education in an external unit, the penitentiary department officers are obliged to determine with a school Director the manner in which the information regarding the inmate's student obligations fulfillment is to be exchanged. 
Apart from executing regular teacher's obligations, the teaching personnel is also bound to cooperate with the school-affiliated penitentiary prison service with regards to, inter alia, exchange of information valuable for the inmate resettlement assessment, suggestions as for awards and disciplinary punishments, encouragement towards further education.

In educational establishments operating in the neighbourhood of penitentiaries the obligatory education is given at the level of elementary and middle school. It is also possible, although not compulsory, to gain a higher level of education or certification through follow-up education or courses. The legislator allows that the latter method could be partially or fully payable.

Theoretically, education in penitentiaries is available for all prisoners. However, taking into account the real potential of penitentiary education in terms of vacant places, capability to assure both safety of the inmates and appropriate criminal proceedings, one can conclude that this form of education applies mainly to convicts. It is worth mentioning at this point that penitentiary systems in other countries, for instance the United States of America, are better organized with this respect, and tuition is provided even in the prisons of the highest security category (Pierzchała, Cekierka, 2008). As a matter of fact, The Ordinance of The Ministry of Justice permits the attendance in tuition of the temporarily arrested, however, taking into consideration the restrictions given therein, such cases are outstandingly rare.

From the organizational point of view education in penitentiary isolation can be divided in multiple manners, depending on the criteria. The first criterion is the obligation of education. In light of this, education can be divided into obligatory, for the prisoners below 18 years old who are subject to compulsory education on the basis of The Education Act, and facultative for the remaining inmates. Another criterion for division is the type of education. A distinction can be drawn here between the regular school system and courses (The Ordinance of The Ministry of Justice from the $13^{\text {th }}$ of February 2004, Dz.U.04.37.337; The Instruction No. 1/2011 of The Director General of The Prison Service). The third criterion is the place of tuition. Three solutions can be found here: tuition in a prison-affiliated school, within the premises of a penitentiary or a remand center (mainly vocational trainings), or within the premises of another establishment (course organizer or university). Another, self-explanatory criterion is the type of school. One can distinguish elementary and middle schools, further education including: vocational education, technical colleges, secondary schools and post-secondary education. There is also a possibility to pursue higher education provided a permission of the adequate penitentiary director is granted.

In Poland there are currently 20 school clusters and centers for lifelong learning which comprise 52 schools of different type, affiliated with 22 penitentiaries and 2 remand centers, inter alia in Wołowo, Włocławek, Potulice and Strzelce Opolskie (Tomaszewski, 2011). Within vocational training the prisoners may 
become certified as short-order cooks, confectioners, painters, paperhangers, hairdressers, carpenters, locksmiths, tinsmiths, electrical fitters, bricklayers, electricians, mechanics and many more. Every year about 3500 prisoners can commence education in those establishments. This constitutes $4,5 \%$ of population in the state of penitentiary isolation. As claimed by Machel following Bramska (Bramska, 2001), the directors of penitentiaries are of the opinion that only 40 to $60 \%$ of prisoner may be qualified for vocational training (Machel, 2008). As stems from the published data, 3459 inmates were students of prison-affiliated schools in academic year 2009/2010. This equals $4,2 \%$ of the total number of prisoner and only 26 of them were university students. The number of alumni corresponding to this period equals 817 , out of which 95 acquired secondary education. There were 1177 vocational trainings held in year 2010 which were attended by 13291 prisoners. In this case 13012 alumni were reported which yields the factor of $97,9 \%$ of passed examination (Tomaszewski, 2011). The inseparable element of vocational training is acquiring practical skills and participation in these activities is compulsory. Practical vocational learning can be achieved through workshops and activities in school-affiliated workrooms, employment in institutions which manufacture product or deliver service convergent with the aimed profession or through a combination of both. In any case, there are no legal limitations as for contractual agreements with these institutions. They can be affiliated with penitentiaries but there is no such obligation. In case of a student's employment convergent with the profession he is being trained for, he shall be excused from the obligation of participation in practical vocational training, certainly for the period of employment. (The Ordinance of The Ministry of Justice from the $13^{\text {th }}$ of February 2004, Dz.U.04.37.337). Nowadays, the prison-affiliated schools face the problem of significantly limited vacant places at the institutions operating in cooperation with penitentiaries which complicates the above-mentioned solution (Hołyst, 2008).

The most recent proposal for the prisoner willing to acquire knowledge is e-learning. This method of education has recently gained a constantly growing multitude of followers among the directors of penitentiaries and remand centers, their staff as well as among the prisoners themselves. This undertaking was inaugurated at the level of secondary school in Warsaw remand centers of Grochów and Białołęka. Currently, the system is working in over thirty penitentiary units and the program embraces about 300 students in groups of 9 to 10 people. The ambition of the learning system creators is to achieve the number of 1000 students in a span of 3 oncoming years. E-learning as a form of free-of-charge education in which the learners communicate with the teachers through a web platform and receive learning materials and exercises by e-mail. In the same way completed homework, questions and doubts are sent to the teachers. The institution which runs such form of training is certified as a public school. The unquestionable advantage of e-learning is the possibility for short-term sentenced prisoners to commence trainings and continue education after they are released from a penitentiary 
or a remand center (Szlęzak - Kawa, 2011). Termination of school or course training is certified with a corresponding diploma or attestation, which must not contain information regarding the fact of gaining education during a prison sentence.

\section{Recruitment Procedure}

During the year there are 2 enrollment sessions: winter semester in the period of 1 to 30 of May and summer semester in the period of 1 to 30 of November. In exceptional circumstances, a candidate may be enrolled during a semester, but not later than in the middle of it, when they shall be obliged to compensate the scope of training lost and sit examination in it (The Ordinance of The Ministry of Justice from the $13^{\text {th }}$ of February 2004).

There are certain measures specified in The Executive Penal Code, and other legal deeds, which need to be undertaken in order for a prisoner to become a student. The first step is defining the conditions of the sentence execution. There is an organ instituted by a penitentiary unit director, called penitentiary committee, comprised of selected officers and employees of the penitentiary, which acts within the competence described in article 76, 1 of The Penal Executory Code. By executing the tasks given in section 1,2 and 3 of the above article, the committee defines the conditions for the prisoner's sentence execution: directs them to an adequate penitentiary and a specfied prison system but also, if necessary, determines individual influence program. These conditions correspond to classification group and subgroup comprised of penitentiary type and nature, and sentence execution system. Polish Law stipulates for types of penitentiaries (for juvenile criminals, first-time prisoners, persistent offenders and the remanded in military custody), three groups of nature (closed, half-open and open) and three systems of sentence execution (correctional, therapeutic and standard) (Lelental, 2010).

After the conditions of sentence execution are defined, the prisoner interested in completing education is obliged to submit application to enroll on a course or receive school education.

A prisoner who is under school obligation is automatically selected as a candidate for tuition. They are introduced to the penitentiary committee, which on the strength of article $76 \S 1$ of The Penal Executory Code qualifies them for tuition. The following aspects are taken into consideration in order to arrive at a decision:

- documented education, which is the basis for tuition in a given school or designated semester,

- motivation of the convict,

- correctional individual tasks and psychological recommendations (if any given),

- general health condition, 
- date of conditional early release and sentence termination,

- professional work practice of the inmate,

- conformance of the chosen school and semester with the updated list of available schools, programs and semesters,

- purpose of the penitentiary affiliated with a school,

- the need to provide order and safety (The Ordinance of The Ministry of Justice from the $13^{\text {th }}$ of February 2004),

Additionally, a candidate who applies for vocational training, course or technical college is obliged to obtain "a medical attestation for no health contraindications to begin training for a chosen profession" (therein §22). It is worth highlighting here that even therapeutic departments were embraced in the recruitment procedure in year 2010. There were 28 prisoners designated to commence school education (any type of school) and 188 enrolled on courses (Tomaszewski, 2011).

Thereafter, the administration department of a penitentiary unit sends a summary name list of candidates to the management of a given school. After the date of country-wide name list submission, the recruitment committee accepts candidates in respective schools, classes and semesters. During its work the committee follows the below assumptions:

- the number of students in the first semester must equal at least 20,

- the number of students in subsequent semesters must not by lower than 10 (The Ordinance of The Ministry of Justice from the $13^{\text {th }}$ of February 2004),

- when the number of candidates transcends the number of vacancies, the priority is to be given based upon the regulations of The Execution Penal Code.

If a prisoner was not qualified as a student of a given school, the director of his penitentiary unit should forward his application to another educational establishment capable of including the prisoner among their students.

In the case when it is obligatory to accept one or several new students with school obligation, tuition can be provided on hourly basis, which is specific for individual mode.

A convict who was given permission for tuition beyond the premises of the penitentiary is obliged to cover the cost of education, with the exception of a situation in which there is no prison-affiliated school providing the selected subject of education. If this is the case, the penitentiary is allowed to fully or partially cover the expenses on handbooks, study aid, stationery and travels. The director of the penitentiary may also permit a convict to participate in tutorial and sit examinations in establishments located outside the penitentiary.

- The Ordinance of The Ministry of Justice determines also the circumstances under which the penitentiary committee may exclude an inmate from further tuition. These are the followingconduct which jeopardizes the safety of a penitentiary,

- refusal to participate in classes,

- declaration of psychological contraindications to continue education, 
- learning interval of more than $50 \%$ of tuition time due to transport by order of disposing party,

- learning interval of more than $50 \%$ of tuition time due to failure to return from temporary release,

- health condition precluding participation in classes,

- no promotion to next semester with no possibility to repeat it (The Ordinance of The Ministry of Justice from $13^{\text {th }}$ of February 2014),

In academic year 2009/2010 there were in total 1014 prisoners excluded from education, out of which 233 for security reasons.

\section{Informal Aspect of Prison-affiliated Schools Operation}

In order to present in full the concept of operation of the schools affiliated with penitentiaries one should not overlook two issues extremely significant from the perspective of successful recruitment. These are: the phenomenon of prison subculture and profit and loss account from the prisoner's point of view.

There have been a number of publications written about prison subculture. It was the main theme of movies, the subject of bachelor's and master's theses. However, these works are not sufficiently earnest in many cases. The reason for this is a lack of trustworthy source of information and the fact of authors being purposefully misguided by the investigated prisoners. The works frequently contain fundamental errors and thus they are unreliable. Nevertheless, this article does not aim to fathom this problem. It is a fact, however, that the place of the inmate in prison subculture determines many aspects of their existence among people bereft of freedom (Kolęda, 1995; Kamiński, 2006). This includes the very possibility to commence education in the school of their choice, type of education and the desirable profession.

Another aspect is a result of polarization of the academic society associated with resettlement issues investigation on one side and prison practitioners on the other. Theoretically, every person interested in correctional actions activities should be satisfied and helpful if an inmate turns to them asking for support and acceptance as a student of a given establishment. However, every prison practitioner will instantly surmise what lies behind the sudden willingness of the prisoner to be qualified for tuition in a particular school. It is worth noticing that the choice of any specific profession, which the prisoner is to be taught, is completely without significance. The key factor to solve this problem is penitentiary court's jurisdiction. Prisoners share information, specific "prison legends" about where it is easiest to obtain early conditional release and which judge is more liberal and who they should not send petitions to. It is worth mentioning that the prisoners do not base on any reliable statistical factsheets, but only the number of petitions 
approved by the penitentiary court regarding early release and prison sentence breaks. Generating this sort of myth, the prisoners make a basic logical mistake of not including in the equation the percentage factor of release.

Another element which encourages inmates to become students, not to learning though, is confidence that it is easier to be rewarded. The author did not find any statistical data to support such statement, but he is of the opinion that if it was the case this would be in contradiction with teacher's ethics. One should bear in mind that students participate in classes in order to achieve knowledge and skills and undergoes correction. In this case, the prisoners who attend classes in prisonaffiliated schools should be the ones who actually want to gain knowledge, are really motivated to change their attitudes and life as a consequence.

The author considers it a mistake to qualify as students all applying inmates, including those who cannot specify the intentions behind application, declare openly their wish to change the surroundings or increase the chances of early conditional release. Undoubtedly, the ones who should serve as the main sieve for selection in this case are pedagogues, prison psychologists and penitentiary committee responsible for decision-making. Nevertheless, in order to enforce such a solution the effective law needs to be modified.

What seems to be another mistake is considering the completion of prison-affiliated school education as an indication of full resettlement and approving early conditional release basing on such assumption. Certainly, the fact that a prisoner is working on themselves and strives to meet the expectations of the penitentiary system should be noted and considered for assessment of their behaviour in the conditions of penitentiary isolation. It is, however, just one of many elements constituting a positive criminal and social forecast.

\section{Discussion}

A fundamental question which frequently appears in discussions of practitioners about prison education concerns the sense of organizing this kind of activities. Even though, tuition is indisputably one of four aspects of interaction between the prisoner and society in the process of resettlement (Machel, 2003), it still arouses controversy. The group of practitioners comprises many supporters of prison-affiliated schools but there are numerous opponents as well. The most frequent arguments mentioned by the former are: education as such, time-consuming activity, gaining qualifications, including vocational, working on prisoners' regularity. Another argument is the prosocial aspect which is worth efforts even if the result is minimal. The process of empathy may be an example of it (Gulin, 2006). The opponents, however, allege that this type of education implicates vast expenditure which does not translate into real benefits, there are no indicators which 
prove the gained knowledge and skills to be utilized in private or business life and that there is no evidence to support the claim of the lawmaker that tuition is one of major and most effective methods of correction.

In order to evaluate reasonableness of continuing prison school education, one should have a look at the benefits and losses resulting from this type of tuition. This aspect should be approach both from the perspective of the prisoner and society through considering different objectives, standards, preferred rules and qualities.

The motivation for school education which is most frequently mentioned by the prisoners is acting against boredom, idleness and conviction that it will increase chances to be approved for early conditional release, which was mentioned before. The will to gain knowledge, explore the world or learning new skills is mentioned extremely seldom. They imply dramatically rarely that science and knowledge are valuable as such, as opposed to the means of obtaining tangible goods only. This can be directly translated into the attitude of the learning inmates towards studied subjects. According to research, their favourite activity is physical education (over $92 \%$ of respondents) and pedagogue - PE teacher ( $88 \%$ of respondents) (Michniewicz, Michniewicz, 2006). Arguments used by families of high pedagogical efficiency are also absent. These are typically used by parents who motivate their children to learn more in general and more effectively, referring to supremacy of knowledge, ambition and channelizing child's activity. What dominates is purely instrumental, proximal attitude deprived of the general social aspect. A very typical trait of the prison environment is extreme materialism, a lack of patience, claiming attitude and external sense of control in case of any failures. As a consequence, there are relatively few inmates willing to participate in stationary education which requires persistent work on oneself, regularity and a sense of obligation. Excessive focus on oneself leads to preservation of egoistic traits, which results in the above-mentioned extreme materialism associated with gaining profit even if at the expense of another person (Gulin, 1994). From the perspective of a prisoner, these are the disadvantages of education which discourage them from attempting to commence education. Taking into account the above, one can conclude why there is much interest in course education among prisoners. Investigating this aspect, one may only distinguish two reasons why prisoners fail to enrol in courses: no interest or capabilities towards a vocation or the attitude of discouragement towards any activity which would breach the current status quo, which is a symptom of prizonization (Badowska - Hodyr, 2008). Prizonization is a phenomenon related to the fact of inmate's adaptation to specific standards of imprisonment such as rules, attitudes, behaviour, language and habits (Ciosek, 2003). The advantage of course training over school tuition is:

- short time of duration (rarely exceeding 150 hours),

- few exams,

- possibility of full cost reimbursement. 
To sum up, the interest in both school tuition and course training frequently deviates from theoretical assumptions, which must have been the inspiration for the people participating in legislative process. The stress laid nowadays upon the number of students or courses, as opposed to choosing only the candidates presenting right attitude and motivation, brings chaos to the recruitment process and allows too large holes in the selection sieve. As a result of such approach, the schools affiliated with prisons may, paradoxically, quickly lose their students expelled for reprehensible behaviour, experience fall general of discipline, and thus more frequently the safety in schools and penitentiaries may be endangered. The solution proposed by the author could be adjusting the places for students in schools to the number of candidates approved for education in their parent units. Certainly, such approach would imply closing some of the subjects or even establishments, but it would be justified by both economical calculation and common sense. There is a contradictive conclusion coming from Tomaszewski, who refers to the investigation of The Central Board of The Prison Service, which indicates that this is insufficient pedagogical staff problem that may complicate accepting more prisoners for education (Tomaszewski, 2011).

The requirement to justify the will to commence education with a cover letter, constituting an integral part of the petition, correct behaviour which was also required before, and promoting those attitudes which are not of claiming nature would preliminarily eliminate those students who would not have a chance to complete education. Maintaining the right attitude in the course of tuition, passed subjects and completing education program within the scheduled timeframe could serve as prerequisite for a leave or early conditional release. With this regard, cooperation between school staff and officers from the penitentiary department would, for sure, increase the likelihood that those desirable traits could strengthen. Considering the possibility to use the technique of personal influence and allowing for the research concluding that a pedagogue can be the authority for prisoners, one can assume that such a solution could bring positive results (Karaszewska, 2008). On the other hand, negative behaviour, absence resulting from the prisoner's malevolence or no will of cooperation with teachers should imply negative decisions as for the above conclusions and proceeding in order to enforce partial or total reimbursement of the education expenses from the prisoner.

From the society point of view, tuition in penitentiaries and remand centers carries benefits as well as losses. Among the former one should distinguish decrease of illiteracy, equalized chances of access to education, increase of the general education level indicator among citizens, probably decreased factor of former prisoners returning to crime (although the author did not encounter reliable statistics to prove this tendency), employment of people committed to engage in prison education. Another benefit is a decrease of the likelihood of 
spontaneous aggressive actions among prisoners through reduction of monotony and idleness. This translates into decreased demand for employment of budget measures (Poklek, 2008).

Another negative aspect, associated with the subject activity, is preservation of the sense of social inequity. At the moment when the majority of society expects a more coercive criminal system (Pawela, 2008), frequently restoration of death penalty, the information about penitentiary education activity, in most cases funded by the nation treasury, may cause social discontent. Free-of-charge vocational trainings and, in many cases, school accessories may certainly arouse objections among the unemployed or living on minimal salary. However, according to Miłkowska, no support from the nation for the imprisoned, in fact caused by fear, results in depriving the prisoners of other options but returning to crime, which may lead to another crime (Miłkowska, 2009). Disadvantages of this type of education are the expenditure related with the maintenance of establishments and external companies which run the courses, and in the author's opinion, not fully appropriate selection of vocational course subjects. Too extensive, country-wide trainings for window fitters or tilers may result in the former prisoners returning to crime. Demoralized people who do not consider social standards in general, will very likely take advantage of their presence in the buyer's apartment to commit another crime. It is worth noticing that course certificates and vocational qualifications achieved in penitentiaries, in accordance with the anti-stigmatization rule, do not include any information about education being completed in a penitentiary or a remand center. As a result, neither employer nor a natural person in search of a professional cannot be sure about true intentions of the person educated, in this context with money from the nation treasury.

\section{Summary}

Taking into account global approach and objective arguments, one should conclude that education in prison-affiliated schools and by course system is certainly an effort of the state, which may bring real benefits in the shape of decrease of the percentage of prisoners returning to crime. Unarguably, prison education system requires many changes both in the realm of legal regulations and organization. Considering frequent modifications of effective law and multi-layer reform of The Prison Service, which aims to reduce the problems spotted within the organization by its high authorities, inter alia: overabundant bureaucracy, dehumanizing influence on the employee and a lack of capability to perform correctional tasks (Keller, Kopczuk, 2006), one may hope that stress will be laid upon common sense and economy as opposed to statistical reports only. 


\section{References}

Badowska - Hodyr, M. (2008). Poziom prizonizacji sprawców przestępstw przeciwko mieniu. [In:] W. Ambrozik, H. Machel, P. Stępniak (red.) Misja Stużby Więziennej a jej zadania wobec aktualnej polityki karnej i oczekiwań społecznych. IV Polski Kongres Penitencjarny. Poznań Gdańsk - Warszawa: UAM, UG, Pedagogium WSPR i CZSW.

Ciosek, M. (2003). Psychologia sądowa i penitencjarna. Wyd.2. Warszawa: Wyd. Prawnicze LexisNexis.

Instrukcja Nr 1/2011 Dyrektora Generalnego Stużby Więziennej z dnia 13 lipca 2011 r. w sprawie szczegółowego trybu organizowania nauczania w szkołach oraz szkolenia kursowego w zakładach karnych i aresztach śledczych.

Gulin, W.(1994). Empatia dzieci i młodzieży. Lublin: TNKUL.

Gulin, W. (2006). Filozoficzne korzenie empatii. Studia Psychologica. Warszawa: Wydawnictwo Uniwersytetu Kardynała Stefana Wyszyńskiego. s. 207- 221.

Hołyst, B. (2008). Oddziaływania penitencjarne jako sposób zapobiegania przestępczości. [In:] W. Ambrozik, H. Machel, P. Stępniak (red.) Misja Stużby Więziennej a jej zadania wobec aktualnej polityki karnej i oczekiwań społecznych. IV Polski Kongres Penitencjarny. PoznańGdańsk - Warszawa: UAM, UG, Pedagogium WSPR i CZSW.

Kamiński, M. M. (2006). Gry więzienne. Tragikomiczny świat polskiego więzienia. Warszawa: Oficyna Naukowa.

Karaszewska, H. (2008). Proces resocjalizacji penitencjarnej w opinii wychowawców więziennych. [In:] W. Ambrozik, H. Machel, P. Stępniak (Eds.) Misja Stużby Więziennej a jej zadania wobec aktualnej polityki karnej i oczekiwań społecznych. IV Polski Kongres Penitencjarny. Poznań Gdańsk - Warszawa: UAM, UG, Pedagogium WSPR i CZSW.

Keller K., Kopczuk J. (2006). Oddziały penitencjarne. Próba wdrożenia nowej struktury organizacyjnej w jednostkach OISW Białystok w latach 2002 - 2006. [In:] K.Keller, J. Kopczuk (Eds.) Nowa struktura organizacyjna jednostek penitencjarnych. Białystok: OISW w Białymstoku.

Kolęda, K. (1995). Klawisze i złodzieje. Warszawa: Polski Dom Wydawniczy Sp.z o.o.

Lelental, S. (2010). Kodeks karny wykonawczy. Komentarz. Wyd.3. Warszawa: Wyd. C.H.Beck.

Machel, H. (2003). Więzienie jako instytucja karna i resocjalizacyjna. Gdańsk: Arche.

Machel, H. (2008). Czy więzienie może wychowywać - spór o poprawczą funkcję wiezienia. [In:] W. Ambrozik, H. Machel, P. Stępniak (Eds.) Misja Stużby Więziennej a jej zadania wobec aktualnej polityki karnej i oczekiwań społecznych. IV Polski Kongres Penitencjarny. Poznań Gdańsk - Warszawa: UAM, UG, Pedagogium WSPR i CZSW.

Michniewicz, I., Michaniewicz, R. (2006). Szkolne wychowanie fizyczne we wspomnieniach skazanych (na podstawie pamiętników). [In:] K. Klukowski, P. Łapiński, A. Wiza, A. Kaczmarek (Eds.) Promocja zdrowia we współczesnym więziennictwie. Kalisz: COSSW, PSNARiT, PTNKF SKFwW.

Miłkowska, G. (2009). Dostrzec w skazanym człowieka. [In:] T. Szymanowski (red.) O pomocy w powrocie do spoleczeństwa. W 100 - lecie powstania Patronatu. Białystok: Stowarzyszenie Penitencjarne Patronat.

Pawela, S. (2008). Społeczeństwo wobec zjawiska przestępczości. [In:] W. Ambrozik, H. Machel, P. Stępniak (Eds.) Misja Stużby Więziennej a jej zadania wobec aktualnej polityki karnej i oczekiwań społecznych. IV Polski Kongres Penitencjarny. Poznań - Gdańsk - Warszawa: UAM, UG, Pedagogium WSPR i CZSW.

Pierzchała, K., Cekierka, C. (2008). Zwalczanie patologii społecznych w systemie penitencjarnym Polski i USA. Toruń: Wydawnictwo Adam Marszałek.

Poklek, R. (2008). Aktywność fizyczna a syndrom agresji osób pozbawionych wolności. Kalisz: COSSW. 
Rozporządzenie Ministra Sprawiedliwości z dnia 13 lutego 2004 r. w sprawie szczegółowych zasad i trybu prowadzenia nauczania w zakładach karnych. Dz.U.04.37.337.

Szlęzak - Kawa, E. (2011). E - learning szansą dla skazanych. Forum Penitencjarne Nr 02 (153).

Tomaszewski, T. (2011). Nauczanie w zakładach karnych. [In:] Oddziaływania penitencjarne i terapeutyczne $w$ zaktadach karnych $i$ aresztach śledczych $w 2010 \mathrm{r}$. Warszawa: CZSW Biuro Penitencjarne.

Ustawa z dnia 6 czerwca 1997 r. Kodeks karny wykonawczy (Dz. U. 97.90 .557 z dnia 5 sierpnia 1997 r.). 